\title{
Evaluation of design manufacturability in new product production launches by Lucas DFA method
}

\author{
Ocena technologiczności konstrukcji \\ w procesach montażu wyrobów metodą Lucas DFA
}

\section{JÓZEF MATUSZEK TOMASZ SENETA*}

DOI: https://doi.org/10.17814/mechanik.2017.7.66
The paper presents the concept of algorithmization of the new product process implementation under the conditions of mass production. It describes the methods and techniques in DFA methodology in the new product production implementation. It was discussed influence of these methods to improve the manufacturability of the complex product assembly.

KEYWORDS: production process design, construction manufacturability, mass production

Contemporary production processes, especially largescale ones, are characterized by a progressive degree of automation of machining and development of cooperation services in the execution of individual components and complex, unified components of the unified components, tailored to the wishes of customers. For this reason, in managing the implementation projects for the production of new products, their design is more and more important considering their assembly technology (PdM) [4, 5].

Different methods are used to evaluate the assembly technology and determine guidelines for shaping the design process due to PdM. In the automotive industry, DFA (design for assembly) methods are widely used, proposed and described for the first time by G. Boothroyd and P. Dewhurst in 1983 "Design for Assembly, A Designers Handbook" [4].

Several methods of DFA $[1-3,5]$ have been described in the literature - the most commonly used in manufacturing practice are presented in table I [5].

\section{Lucas DFA method}

This method is used to analyze the manual and/or automatic assembly technology. The Lucas DFA rating is based on the definition of three indicators whose values are related to the relative measure of difficulty of assembly. Its purpose is to reduce the number of assembled components of the final product and to analyze assembly operations for difficulties, complexity and time consuming.

The Lucas DFA procedure is shown in figs. 1-3. The project is subjected to a functional analysis that evaluates the functions of the individual components and whether they are necessary. A feasibility study is then carried out, including analysis of the assembly and maneuvering of the assembled components and the method of assembly itself.

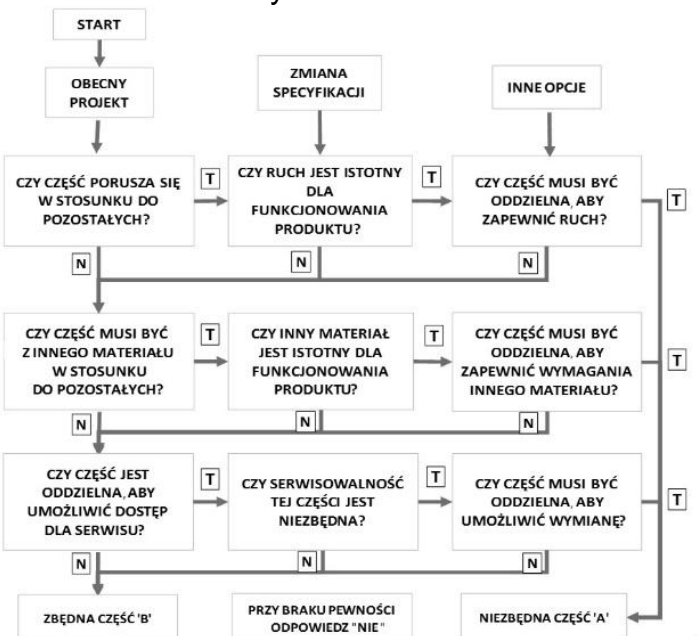

Fig. 1. Lucas DFA functional analysis scheme [8]

The $W_{e p}$ efficiency index based on functional analysis is as follows:

$$
W_{\mathrm{ep}}=\frac{L_{\mathrm{kA}}}{\left(L_{\mathrm{kA}}+L_{\mathrm{kB}}\right)} \cdot 100 \%
$$

where: $L_{k A}$ - number of components $A$ (fulfilling product function), $L_{k B}$ - number of components $B$ (not fulfilling product function, e.g. rivets or washers).

TABLE I. Summary and methodology of selected DFA methods $[1,7]$

\begin{tabular}{|c|c|c|c|}
\hline Method & Year & Inventors & Description \\
\hline Lucas DFA & 1980 & A.H. Redford, K.G. Swift & $\begin{array}{c}\text { It is based on SSM - Assembly Sequence Diagram - evaluating assembly design. } \\
\text { It evaluates and aggregates penalty points related to product design issues }\end{array}$ \\
\hline $\begin{array}{c}\text { Hitachi Assimilability } \\
\text { Evaluation Method } \\
\text { (AEM) }\end{array}$ & 1986 & S. Miyagawa, T. Ohashi & Assesses the product's mountability and cost ratio to identify product design \\
weaknesses
\end{tabular}

* Prof. dr hab. inż. Józef Matuszek (jmatuszek@ath.bielsko.pl), mgr inż. Tomasz Seneta (kip@ath.bielsko.pl) - Akademia Techniczno-Humanistyczna w Bielsku-Białej, Wydział Budowy Maszyn i Informatyki, Katedra Inżynierii Produkcji 


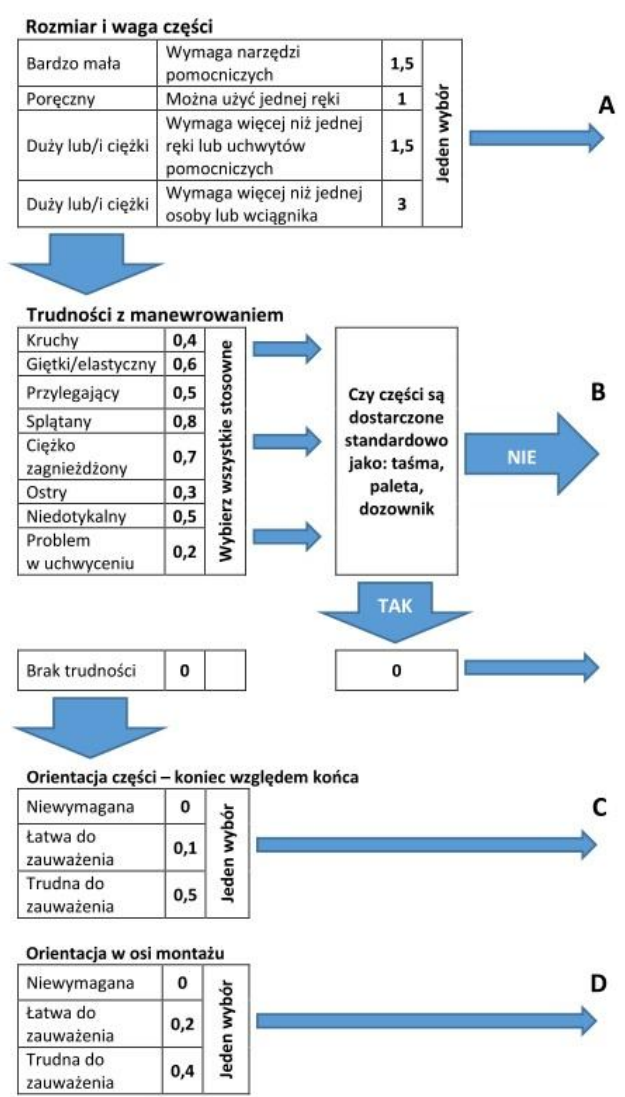

Fig. 2. Scheme of scoring in maneuver analysis in the Lucas DFA method [8]

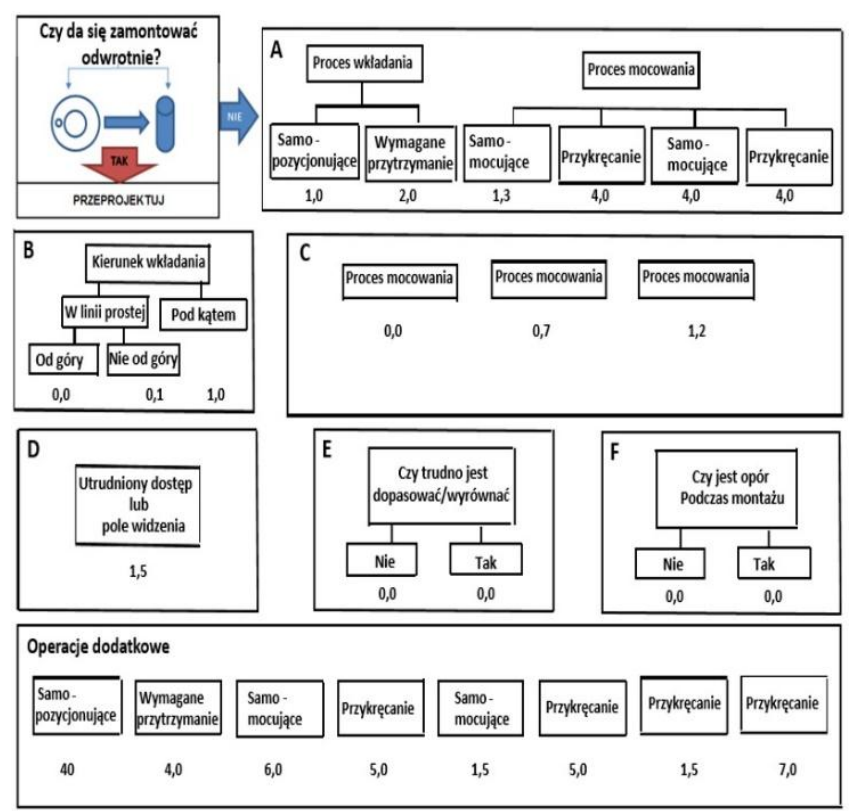

Fig. 3. Scheme of scoring in Lucas DFA mounting analysis [8]

Maneuvering coefficient $W_{\operatorname{man}}$ is defined by the formula:

$$
\begin{gathered}
W_{\text {man }}=I_{\text {man }} / L_{\mathrm{kA}} \\
I_{\text {man }}=L_{\mathrm{pA}}+L_{\mathrm{pB}}+L_{\mathrm{pC}}+L_{\mathrm{pD}}
\end{gathered}
$$

where: $I_{\operatorname{man}}$ - maneuvering index, $L_{k A}$ - number of A components (fig. 2); $L_{P A}, L_{D B}, L_{D C}, L_{D D}$ - sum of points from segments $A, B, C$ and $D$ (according to fig. 3 ).

The model describing the results of the manufacturability coefficient $W_{\text {mon }}$ analysis of the Lucas DFA method (fig. 3) has the form:

$$
W_{\text {mon }}=\frac{W_{\mathrm{m}}+W_{\mathrm{d}}}{L_{\mathrm{kA}}}
$$

where: $W_{m}$ - main activity indicator $\left(W_{m}=L_{m A}+L_{m B}+\right.$ $\left.L_{m C}+L_{m D}+L_{m E}+L_{m F}\right), W_{d}$ - additional activity indicator, $L_{k A}$ - number of $A$ components (fig. 1).

\section{Example}

A single-stage prototype design was subjected to the Lucas DFA (fig. 4). The construction was designed on a production basis. For the accepted production conditions, the assembly process is defined. For each mounted part and for each defined step (table II) of the assembly process, the $W_{e p}, W_{\operatorname{man}}$ and $W_{\text {mon }}$ values were calculated:

$$
\begin{gathered}
L_{\mathrm{kA}}=24, L_{\mathrm{kB}}=81, L_{\mathrm{kA}}+L_{\mathrm{kB}}=105 \\
W_{\mathrm{ep}}=24 / 105=0,23=23 \% \\
I_{\text {man }}=L_{\mathrm{mA}}+L_{\mathrm{mB}}+L_{\mathrm{mC}}+L_{\mathrm{mD}}=48+10,9+2,7+5,6=67,2 \\
L_{\mathrm{kA}}=24 \\
W_{\mathrm{man}}=67,2 / 24=2,8 \\
W_{\mathrm{m}}=L_{\mathrm{mA}}+L_{\mathrm{mB}}+L_{\mathrm{mC}}+L_{\mathrm{mD}}+L_{\mathrm{mE}}+L_{\mathrm{mF}}=108,2+2,1+ \\
+10,5+18+11,9+7+126,5=284,2 \\
L_{\mathrm{kA}}=24 \\
W_{\text {mon }}=284,2 / 24=11,84
\end{gathered}
$$

On the basis of such defined values of the index and coefficients, it is possible to proceed to shaping the design of the product from the point of view of technological assembly. Due to market demand, production costs and delivery times to the customer, general purpose gearboxes are designed in the form of series. The series consists of several gears with the same design but different geometric dimensions.

The results of the analysis for the assumed course of assembly are presented in Table. II. It contains selected operations assigned to the analysis: functionalities (in the form of components included in group A or B - fig. 1), maneuvering (within segments $A, B, C$ and $D-$ fig. 2), and mountability (according to major activity indicators $A$, $\mathrm{B}, \mathrm{C}, \mathrm{D}, \mathrm{E}$ and $\mathrm{F}$ and additional operations. For additional operations, see the Sec column.

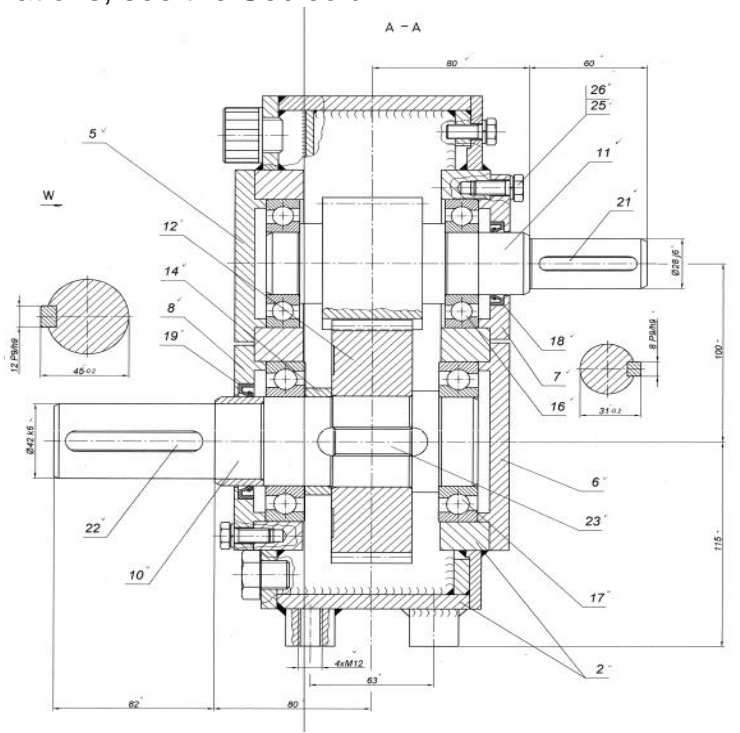

Fig. 4. Diagram of analyzed gearbox: 2 - body; 5, 6, 7, 8- bearing caps; 10 - roller; 11 - pinion; 12 - toothed wheel; 14 - spacers; 16 , 17 - bearings; 18,19 - seals; 21, 22, 23 - inlets; 25, 26 - washers, screws 
TABLE II. Results of the gearbox assembly technology analysis of fig. 4

\begin{tabular}{|c|c|c|c|c|c|c|c|c|c|c|c|c|c|c|c|c|c|c|c|c|}
\hline & Krok montażu & Opis & $\begin{array}{c}\text { Analiza } \\
\text { funkcjonalna }\end{array}$ & & & A & B & C & D & Suma & & A & B & c & D & E & $\mathbf{F}$ & Sec. & Suma & $\begin{array}{c}\text { Suma } \\
\text { narastająco }\end{array}$ \\
\hline 1 & Pobranie & Korpus & A & 1 & & 3 & 0 & 0 & 0 & 3 & Pobranie i posadowienie & 1 & 0 & 0 & 0 & 0 & 0 & 0 & 1 & 1 \\
\hline 2 & Prasowanie do korpusu & Łożysko 16 & A & 1 & & 1 & 0,4 & 0 & 0 & 1,4 & Prasowanie & 1 & 0 & 0 & 0 & 0 & 0,7 & 0 & 1,7 & 2,7 \\
\hline 3 & & & & & & & & & & & Pomiar pozycji łożyska & 1,3 & 0,1 & 0 & 1,5 & 0 & 0 & 1,5 & 4,4 & 7,1 \\
\hline 4 & Prasowanie do korpusu & Łożysko 17 & A & 1 & & 1 & 0,4 & 0 & 0 & 1,4 & Prasowanie & 1 & 0 & 0 & 0 & 0 & 0,7 & 0 & 1,7 & 8,8 \\
\hline 5 & & & & & & & & & & & Pomiar pozycji łżyska & 1,3 & 0,1 & 0 & 1,5 & 0 & 0 & 1,5 & 4,4 & 13,2 \\
\hline 6 & Prasowanie do łożyska 16 & Wałek zębaty & $\mathbf{A}$ & 1 & & 1 & 0 & 0,1 & 0,2 & 1,3 & Pobranie i przytrzymanie & 1 & 0 & 0 & 0 & 0 & 0 & 0 & 1 & 14,2 \\
\hline 8 & Pobranie & Wakek wolnoobrotowy & A & 1 & & 1 & 0 & 0,1 & 0,2 & 1,3 & Pobranie i posadowienie & 1 & 0 & 0 & 0 & 0 & 0 & 0 & 1 & 18,6 \\
\hline 9 & Montaż & Wpust 23 & B & & 1 & 1 & 0 & 0 & 0,2 & 1,2 & Montaż na zespół wałka & 1 & 0 & 0 & 0 & 0,7 & 0 & 0 & 1,7 & 20,3 \\
\hline 10 & Montaż na zespół wałka & Koło zębate 5 & B & & 1 & 1 & 0,4 & 0,1 & 0,2 & 1,7 & Montaż na zespół wałka & 2 & 0,1 & 0 & 0 & 0,7 & 0,7 & 0 & 3,5 & 23,8 \\
\hline 11 & Montaż na zespół wałka & Tuleja dystansowa 14 & B & & 1 & 1 & 0 & 0 & 0 & 1 & Montaż na zespół wałka & 1 & 0,1 & 0 & 0 & 0 & 0 & 0 & 1,1 & 24,9 \\
\hline & & & & & & & & & & & & & & & & & & & & \\
\hline 55 & Montaż na zespół wałka & Wpust pryzmatyczny 22 & B & & 1 & 1 & 0 & 0 & 0,2 & 1,2 & Montaż na zespół wałka & 1 & 0 & 0 & 0 & 0,7 & 0 & 0 & 1,7 & 243,3 \\
\hline 56 & Montaż do korpusu & Odpowietrznik 27 & A & 1 & & 1 & 0 & 0,1 & 0,2 & 1,3 & Pobranie i posadowienie & 1 & 0 & 0 & 0 & 0 & 0 & 0 & 1 & 244,3 \\
\hline 57 & & & & & & & & & & & Przykręcanie & 4 & 0,1 & 0 & 0 & 0 & 0 & 0 & 4,1 & 248,4 \\
\hline 58 & Montaż do korpusu & Olejowskaz 28 & A & 1 & & 1 & 0 & 0,1 & 0,2 & 1,3 & Pobranie i posadowienie & 1 & 0 & 0 & 0 & 0 & 0 & 0 & 1 & 249,4 \\
\hline 59 & & & & & & & & & & & Przykręcanie & 4 & 0,1 & 0 & 0 & 0 & 0 & 0 & 4,1 & 253,5 \\
\hline 60 & Montaż do korpusu & Korek 29 & A & 1 & & 1 & 0 & 0,1 & 0,2 & 1,3 & Pobranie i posadowienie & 1 & 0 & 0 & 0 & 0 & 0 & 0 & 1 & 254,5 \\
\hline 61 & Montaż do korpusu & Pierścień uszczelniający 30 & A & 1 & & 1 & 0 & 0,1 & 0,2 & 1,3 & Zalożenie na korek & 1 & 0,1 & 0 & 0 & 0 & 0 & 0 & 1,1 & 255,6 \\
\hline 63 & Pobranie i ustawienie & Tabliczka znamionowa & B & & 1 & 1 & 0,2 & 0,1 & 0,2 & 1,5 & Pobranie i posadowienie & 2 & 0,1 & 0 & 0 & 0,7 & 0 & 0 & 2,8 & 262,5 \\
\hline 64 & Nitowanie & Nitokołek & $B$ & & 1 & 1,5 & 0,2 & 0 & 0 & 1,7 & Pobranie i posadowienie & 2 & 0,1 & 0 & 0 & 0 & 0 & 0 & 2,1 & 264,6 \\
\hline 65 & & & & & & & & & & & Nitowanie & 4 & 0,1 & 0 & 0 & 0,7 & 0 & 0 & 4,8 & 269,4 \\
\hline 66 & & & & & & & & & & & Dodatkowe nity & 2 & 0,1 & 0 & 0 & 0,7 & 0 & 12 & 14,8 & 284,2 \\
\hline 82 & & & & & & & & & & & & & & & & & & & & 284,2 \\
\hline 83 & & & & & & 48 & 10,9 & 2,7 & 5,6 & 67,2 & & & & & & & $\overline{-}$ & & & 284,2 \\
\hline 84 & & & & 24 & 81 & & & & & & & 108,2 & 2,1 & 10,5 & 18 & 11,9 & 7 & 126,5 & & $\begin{array}{r}284,2 \\
\end{array}$ \\
\hline & & \multicolumn{2}{|l|}{$23 \%$} & & & \multicolumn{5}{|c|}{2,80} & & & & & & & & & & 284,2 \\
\hline & & Wskaźnik efektywnos & & & & & skaźnil & k man & ewrow & rania & & \multicolumn{8}{|c|}{ Wskaźnik montowalności } & 11,84 \\
\hline & & & & & & & & & & & Montowanie & & & & & & & & & \\
\hline
\end{tabular}

In the illustrated example, the developed design (fig. 4) is non-technological in view of the potential for mass production. In the evaluation method used, the project efficiency index is $W_{e p}=23 \%$ (authors of the publication [8] report value of $60 \%$ as a minimum) and $W_{\operatorname{man}}=2.8$ and $W_{\text {mon }}=11.84$ (according to [8], both indicators should be less than 2.5).

To improve the technology of gearbox assembly, following aspects should be considered:

- within the scope of application of the new construction: changing the structure of the body (for example, cast iron instead of welded steel body), analysis of the component minimization, unification of components included in the gear unit (gear elements, body cover, sight glass, fasteners - bolts, washers);

- regarding to the application of a new assembly structure: assembly of assemblies - e.g. shaft with mounted gear and bearings, pinion with bearings using appropriate mounting equipment.

Although the Lucas DFA method presented in the article is related to the mass production, it can also be used in certain situations when it is less productive.

\section{Conclusions}

By analyzing the values of the parameters of technological evaluation of the gearbox assembly, it can be stated that:

- evaluation of parameter values (table II) may be the basis for the analysis of the design of the product design,

- assessment should take into account many other factors related to sales, service, availability of spare parts, production volumes, types of equipment, available assembly techniques, level of automation, cooperation services, commercial components, crew technical culture, etc.

Lucas DFA analysis is one of several methods for evaluating the technology of a product's design - it allows assessment of assembly technology in terms of time criterion and thus assembly costs.

The method can be successfully applied also to smaller batches of manufactured products for the manufacture of a group of technologically similar products - e.g. general purpose gears.

The use of standardization of assembly operations is helpful in assessing construction - it makes it easier to determine the time of these operations.

The ability to evaluate the design is conducive to the creativity of the designers - procedure discussed in the paper can be carried out for the product and its components (assemblies, components, etc.).

\section{REFERENCES}

1. Abdullah A., Popplewell K., Page C.J. "A review of the support to tools for the process of assembly method selection and assembly planning". International Journal of Production Research. 41, 11 (2003): s. 2391-2410.

2. Egan M. "Design for assembly in the product development process - design theory perspective". Thesis for the degree of Licenciate of Engineering. Report No. 1997-11-14. Chalmers, 1997.

3. Favi C., Germani M., Mandolini M. "Design for manufacturing and assembly vs. design to cost: toward a multi-objective approach for decision-making strategies during conceptual design of complex products". Procedia CIRP. 50 (2016): s. 275-280.

4. Kuo B.T.C., Huang S.H., Zhang H.C. "Design for manufacture and design for ' $X$ ': concepts, applications, and perspectives". Computers \& Industrial Engineering. 41, 3 (2001): s. 241-260.

5. Matuszek J., Seneta T. „Algorytmizacja procesu wdrażania nowego produktu w warunkach wielkoseryjnej produkcji”. Mechanik. 7 (2016): s. 755-757.

6. Pasichnyk V., Lashyna Y. „Montażowo zorientowane projektowanie z zastosowaniem DFA Expert". Zeszyty Naukowe Politechniki Rzeszowskiej-Mechanika. 279 (2011): s. 9-16.

7. Praca zbiorowa. 1995. Advanced Product Quality Planning (APQP) and Control Plan. Reference Manual. AAIG - Chrysler Corporation, Ford Corporation, General Motors Corporation. Adare Carvin., Unit 1, Trade Link, Western Ave, West Thurrock, Grays, Essex England (norma branżowa).

8. Swift K., Brown N. Design for Assembly/Manufacturing Analysis Practitioners Manual (version 10.5). University of Hull, 1994. 